\title{
Implications for Libraries of the National Sea Grant College and Program Act of 1966
}

The National Sea Grant College and Program Act of 1966 provides that $\$ 20,000,000$ will be spent for the development of Sea Grant Colleges. Congressional approval of this act characterizes a general awareness of the need for development of marine resources and recognition that institutions of higher learning are the best agents for training manpower and conducting basic research in this field. The educational and library implications are far reaching.

$T_{1}$ National Science Foundation is presently considering proposals from a number of institutions which possess the necessary laboratory facilities, research vessels, and curriculum development to qualify for receipt of Sea Grants. The effect upon the institutions designated as Sea Grant Colleges will be felt immediately in a proliferation of research projects and marine science curriculum development.

Under the National Sea Grant College and Program Act of 1966, PL 89-688, the National Science Foundation is charged with administering $\$ 20,000,000$ in federal funds through the fiscal year ending June 1968, for the establishment and development of Sea Grant Colleges and research programs in the fields of marine science, engineering, and related disciplines. ${ }^{1}$ According to the Act, development of marine resources includes conservation and economic utilization of

${ }^{1}$ U.S. Statutes at Large, LXXX, 998.

Mr. Durrance is Librarian of the FisheriesOceanography Library in the University of Washington. natural resources; development of marine commerce and engineering; oceanography; and study of the economic, legal, medical and sociological problems arising out of the management and control of the natural resources of the marine environment. The Act defines the marine environment as the oceans, the continental shelf, and all submerged lands to a depth of two hundred meters, as well as the Great Lakes, and all similar submarine areas adjacent to the United States and its territories.

The proposal for a Sea Grant College was first introduced in 1963 at the ninety-third annual meeting of the American Fisheries Society." The term "Sea Grant College" was used to draw a parallel between the present need for ocean resource development and the need for development of land at the time of the Morrill Act of 1862 which established the Land Grand Program. The idea attracted support and resulted in the Conference on the Concept of a Sea Grant University at Newport, Rhode Island, in

${ }^{2}$ American Fisheries Society. Transactions, XCIII (1963), 120-21. 
October $1965 .^{3}$ At this conference the concept crystalized and the process of developing the enabling legislation began as more than two hundred delegates from thirty states, representing institutions of higher learning, private industry, and state and federal governmental agencies discussed the need for and promise of development of marine resources.

The long-range implications of the Act are far broader than first examination might indicate. The past two decades have witnessed a proliferation on a world-wide scale of an awareness of the vast potential of the seas and their profound effects upon the land. Improving the efficiency of fisheries, control of water pollution, mining the sea floor, experiments with undersea dwellings, farming the sea, desalination of sea water, and weather modification are but a few of the areas in which research is presently being conducted. This trend toward development of marine resources and exploration of the seas can only be expected to continue to increase, and virtually every field of science is likely to conduct research related to the marine environment.

The true significance of the National Sea Grant College and Program Act of 1966 lies not in its relatively modest beginning of funding a few more research projects, but rather in the fact that the Congress has shown by its enactment an awareness of a need for developing the potential of the oceans and furthermore has rightfully placed the responsibility for this development, especially the training of manpower and basic research, upon the shoulders of the institutions of higher learning.

At the present time there are sixtyfour institutions of higher learning with curricula oriented toward the marine sci-

${ }^{3}$ Proceedings of the National Conference on the Concept of a Sea Grant University. Kingston, Rhode Island: University of Rhode Island Graduate School of Oceanography, 1965. 96p. ences. ${ }^{4}$ Thirty-four offer programs leading to a PhD degree in either oceanography, marine science, ocean engineering, or fisheries; thirty-five offer master's degree programs, and fourteen offer bachelor's degrees. Forty-seven institutions offer marine sciences courses at the graduate and undergraduate levels which may be applied to related degrees, but do not offer degrees specifically in the area.

In the next decade we may expect a very large increase in the number of graduate and undergraduate level courses being taught relating to the marine environment, as well as an increase in the number of institutions teaching them. The development will affect many parts of the university curriculum. Courses can be expected to be developed in areas now generally considered to be unrelated to the marine environment and to extend into such diverse fields as medicine, law, sociology, economics, political science, and business, as well as engineering and the traditional sciences.

Library collections will, of course, be expected to keep pace in order to support the teaching and research resulting from this new thrust seaward. A considerable increase may be expected in the volume of publication in the field. In addition to the usual problems associated with acquiring and processing this expected flood of publications, the problem of easy access to library material must be solved.

Consolidation and improvement of bibliographic control over the technical reports, translations, and government documents, as well as over trade books and journals will be a necessity. The indexing is presently scattered throughout many sources and is often inadequate. There is a need for a rapid informationtransfer network such as is currently

\footnotetext{
${ }^{4}$ U.S. National Council on Marine Resources and Engineering Development, University Curricula in the Marine Sciences Academic Year 1967-68. Washington, D.C.: U.S. Interagency Committee on Oceanographv Pamphlet No. 30, 1967, 157p.
} 
being developed in the medical sciences. Finally, methods for supporting teaching and research at a growing number of coastal marine research institutes and stations, often hundreds of miles from the parent institution, either through collection duplication or rapid transmission of information, must be developed. While on-site research is not unique to marine science, it is, by the very nature of the subject, characteristic of it.

The National Sea Grant College and
Program Act of 1966 is significant legislation which will probably alter the direction of curriculum development and research in many institutions of higher learning. The extent to which this is true is, of course, dependent upon the continuation of the current trend for the federal government to support development of marine resources. All indications seem to be that this trend will both continue and increase.

\section{UGANDA}

(Continued from page 209)

as university library buildings from the start, are a far cry from the inadequately planned development of the physical plant at Makerere, which remains nothing more than a small residential college library. Moreover, one cannot help contrasting the enthusiasm and high morale in these two libraries with the cloud which has hung over the Makerere library during the last year or two.

If one accepts as fundamentally sound the following statement made by the university grants committee in England as far back as 1924, he can make his own deductions accordingly from the information adduced herein. Commenting on the condition of university libraries in England, the committee expressed itself thus: "The character and efficiency of a University may be gauged by its treatment of its central organ-the Library. We regard the fullest provision for library maintenance as the primary and most vital need in the equipment of a University. An adequate Library is not only the basis of all teaching and study; it is the essential condition of research, without which additions cannot be made to the sum of human knowledge." It seems hardly worth pointing out that the University Grants Committee was not composed of librarians.

However one looks at it, the future of Makerere University College is integrally tied to what it does with its library. In this respect, it would hardly seem unfair to conclude that the Big Brother of universities in eastern Africa has become a doddering reactionary, sitting at a fork in the road, looking backward over the way he has come and muttering foolishly about his own supposed greatness, while his more vigorous and progressive younger brothers overtake and stream past him up both forks of the road. 